\title{
Development of Waterfront City as Destination Product in the Musi River Area, Palembang City
}

\author{
Pandita Nandana ${ }^{1}$, Muhammad Iqbal $^{2 *}$ Handika Fikri Pratama $^{3}$ \\ 1,2, ${ }^{3}$ Palembang Polytechnic of Tourism \\ "Corresponding author. Email: muidjohan@ poltekpar-palembang.ac.id
}

\begin{abstract}
The rationale for this research is the development of the concept of waterfront city development that has been widely adopted by many countries in the world. Waterfront areas are part of the city's physical elements that are very potential to be developed into a livable area and community gathering place. In its development the Waterfront Concept in several countries in the world has a concept that tends to be the same. Waterfront development should be able to be managed optimally to highlight the potential and characteristics of each region. To present an effective and functional development concept, it needs to be controlled by considering aspects both physically and non-physically. With emphasis on the environment and function. Aspects of consideration are obtained based on literature studies. The results of the study show that in waterfront development it is important to harmonize the city / land and water so that they can play a reciprocal role. The reciprocal relationship between them can create a well-organized environment that also presents functions that facilitate activities in the waterfront area more effectively and functionally.
\end{abstract}

\section{Keywords : Waterfront, Waterfront City}

\section{INTRODUCTION}

\subsection{Background}

The Musi River area is also contained in the Palembang City Spatial Plan (RTRW), written in article 7 paragraph 6 , that improving the function of the city as a center of international scale services and trade and developing tourism areas in the Musi River Area is in accordance with its potential, characteristics and make superior tourism. Settlements developed into cities along the banks of the river, left and right of the river parallel to the road established or built various buildings, buildings and houses needed for residential settlements, factories, industries and others. This is what makes this Musi river coastal area dirty, dirty and polluted, so that the coastal area of this river becomes unsightly and also makes this area a loss of its function as an industrial area and tourism activities as previously explained in the Tata Plan. Regional Space (RTRW) of the city of Palembang. Due to these matters, the Palembang city government faces various problems such as: 1) Land use that is not in accordance with its function, if seen based on existing regulations, as industrial estates and tourism activities. 2) Many buildings that grow without the control of the government, causing the shape of buildings that are not in accordance with the local climate in the region. 3) The emergence of environmental problems such as pollution and aesthetic degradation of the city due to the growth of many uncontrolled settlements.

\subsection{Research focus}

1. What is the actual condition which includes physical and non-physical aspects in the Musi river area as the waterfront city of Palembang? 
2. What are the obstacles in the development of the waterfront city in Palembang as a tourism destination?

3. What are the steps for developing the waterfront city in Palembang as a tourism destination?

\subsection{Benefit of research}

Arranging and presenting the development model that will be carried out in the waterfront area, as a tourist area that accommodates water and waterfront recreational activities, themed and with local character background and incorporating these elements into planned recreational activities and facilities in the form of space programs and building design considerations. against local climate conditions in the region.

\section{LITERATURE REVIEW}

\subsection{Waterfront Development}

An area bordering water does not necessarily become an urban waterfront. A structuring and development process is needed called waterfront development. What is meant by waterfront development is an effort to develop urban areas that are physically close to water where the development of urban face development takes place oriented towards the waters, where the scale of activities and functions is very diverse both for housing, port and commercial trade functions and industry to tourist areas (Torre, 1989). The success factors in waterfront development according to Torre (1989), are "In the development of waterfront areas must raise the uniqueness and characteristics possessed by the developed area". These characteristics are divided into two, including physical and non-physical characteristics. Physical characteristics include landscape and environment, access, image, building and landscape arrangement. Whereas the nonphysical character includes the theme of development, activity and utilization of water. Following are the principles used in developing waterfront areas, including: 1) Cooperation from various parties in developing the waterfront area as an attraction for tourists. 2) Development of the water edge concept through the potential that exists in the region as an attraction for tourists visiting the region. 3) Development of activities in the waterfront area and enjoying activities around the port as a potential to provide a valuable experience for tourists, such as dinner, shopping, and others. 4) Development of waterfront areas as recreational orientation, can be in the form of activities and other supporting facilities.
Previous research related to the readiness to organize sports events in South Sumatera showed that the satellite cities of Palembang City, namely Banyuasin Regency and Ogan Ilir Regency, both resulted in the physical dimensions of the city having no significant effect (Karo Karo et al., 2020). In other words, it can be assumed that the two regions have not developed the physical city to the maximum, so this can be a consideration in preparing new tourist destinations in Palembang City.

\subsection{Sustainable Tourism}

Sustainable Tourism is closely related to the balance between processes that occur in nature, such as humans, social life, culture, natural surroundings and the environment that can be enjoyed for future generations. According to the WTO (World Tourism Organization), "Directing the management of all resources in such a way that economic, social and aesthetic needs can be met while maintaining cultural integrity, essential ecological processes, biodiversity and life support systems". The conditions that must be met in guaranteeing the sustainability of tourism according to (Weber, 2006), are as follows: 1) The willingness of tourists to consume tourism services and services products selectively (not exploit). 2) Tourism products are directed towards products that are environmentally based. 3) Tourism activities are intended to preserve and be sensitive to the environment. 4) The role of the community must be involved in planning, implementation, and monitoring

\section{RESEARCH METHODS}

\subsection{Research Design}

The research method used in this research is descriptive explorative with a qualitative approach. The design of this study is used by researchers to conclude the results of research based on the data obtained and the theory to explain

\subsection{Participants and Research Site}

Participants in this study were the Secretary and Head of the South Sumatra Province Tourism Destination Division, Head of the City of Palembang Tourism Attractiveness, Head of Kampung Kapitan RT, Chairman of the Arab Village RT Al Munawar, Kemaro Island manager and POKDARWIS deputy chairperson Musi river. This research was carried out in the Musi river area of Palembang city, which consisted of four loci namely Benteng Kuto Besak, 
Kampung Kapitan, Kampung Arab Al Munawar and Pulau Kemaro.

\subsection{Data Collection}

The process of retrieving primary data is done through direct observation, in-depth interviews and documentation and also secondary data retrieval processes through the Provincial and City Tourism Offices

\subsection{Analysis Technic}

The analysis technique used is Data Triangulation, where there are four stages of the process, namely the process of collecting data, reducing data, presenting data and drawing conclusions. The four stages are carried out to analyze the data obtained from the results of field research and obtain conclusions regarding the research conducted

\section{RESEARCH RESULTS AND DISCUSSION \\ 4.1 Actual Condition for Physical and Non Physical Aspect}

\subsubsection{Physic}

1. Lanscape and Environment

Landscapes and the Environment pollution of waste found on the river lip has a bad impact on the environment around the waterfront area. Pollution occurs because of a lack of public awareness of the importance of maintaining environmental quality. In addition to waste pollution, there are also vandalism at some points which can reduce the beauty and cleanliness of the waterfront area. The small number of plants in this area can also reduce beauty and comfort, because during the day the waterfront area will feel hot and hot. In addition, the function of existing plants is to reduce noise from ship activities

2. Accesibility

The location of this area is in the middle of Palembang city. The location of BKB is also very easy to reach because it is very close to accommodation facilities and the entrance of Palembang city such as airports, seaports and stations. This has a good impact on tourism activities in the city of Palembang, because the strategic location can provide ease of achievement and interest for prospective visitors
3. Image of the Building

The ancient Keraton building model that is still maintained until now will provide more value for visitors. Maintaining this model will provide more value for tourists, because it can provide a different experience

4. Lanscape Arrangement

The absence of pedestrian lanes in the waterfront area will have an impact on the activities of visiting tourists. The importance of the pedestrian lane in the waterfront area is as a place for pedestrians, which is also used as an activity in the waterfront area. The small amount of parking capacity can affect the number of visitors who come. This lack of parking capacity occurs due to the lack of optimal land use in carrying out a previous development. The direction of development in the BKB area is not yet fully facing the water and there is still a small amount of land that is open.

\subsubsection{Non Physic}

1. Development

Theme The theme of development that adapts to historical buildings in the form of the Ancient Palace in the previous period, namely in the era of Darussalam. This will have a positive impact on waterfront city development.

2. Activities

These activities are sufficient and in accordance with the theory used. As Torre (1989) said, the development of activities in the waterfront area and enjoying activities around the harbor is a potential to provide a valuable experience for tourists, such as dinner, shopping and others. Even though in this BKB area, the activity was in accordance with the theory, but there was still a lot of potential for additional activities by utilizing land that had not been used as a container for tourist activities

3. Water Utilization

What is done by the community is in accordance with the applied concept, which is a container for activities or activities that can provide benefits to the community

\subsection{Constraints - Development}

1. The absence of special regional regulations in the Musi River area as a waterfront city, related to the problem of determining zones that will be utilized in its construction. 
2. There is still a lack of synergy between the government and the community in an effort to develop in this region. With the lack of synergy between the government and the community, it will lead to misunderstandings that result in disagreements between the government and the community.

3. There is no awareness from the community in the importance of maintaining environmental quality.

4. There is still a small amount of junk boxes in the waterfront area, especially in Kapitan Village. This will create the potential to dispose of waste improperly, because of the amount of garbage available that cannot accommodate a large amount of waste.

5. The small number of green plants that grow in the waterfront area, such as BKB, Kapitan Village and Al Munawar Arab Village. The small amount of green plants will affect the comfort factor, because the function of green plants is as a noise absorber, making the place protected from the heat of the sun as well as absorption of water.

6. Still lack of activities that can be done by tourists. By having a lot of activities, visitors will take longer to visit. Another case with little activity, will tend to make visitors become bored during their visit.

\subsection{Development Steps}

1. Increasing coordination between tourism stakeholders. Increased coordination is carried out so that community needs can be conveyed to the government and collaborating between the government and the private sector that supports investment, where the collaboration is mutually beneficial, and the comfort and needs of visiting tourists will be fulfilled

2. Revitalize the Musi River area, which has the potential to be developed into a waterfront city as a tourist destination product in the city of Palembang.

3. Approach the community, to support this activity. This approach was carried out as a socialization of the benefits obtained by the community in a waterfront city development.

4. Improve the competence of human resources (HR), in terms of service to tourists who come and also benefit from the importance of protecting the environment in a tourism destination area.

\section{CONCLUSION}

\subsection{Physical and Non Physical Actual Conditions}

1. Benteng Kuto Besak area is not yet in accordance with the theory of waterfront city, so it is necessary to develop in accordance with its potential, such as unused land use, optimization of ease of achievement, cleanliness and beauty of the environment for visitors and environmental sustainability, and maintaining a local climate the development process. The actual conditions on non-physical aspects that are in accordance with the waterfront city theory used are the themes of development, water use and activities that are appropriate even though there is still a need for additional activities so that visitors do not feel bored.

\section{Kapitan Village}

The Kapitan Village area is not in accordance with the theory of waterfront city, so it is necessary to develop in accordance with its potential, such as land use that has not been used, optimizing ease of achievement, cleanliness and beauty of the environment for visitors' convenience and environmental sustainability, and maintaining a local climate the development process. The actual conditions on non-physical aspects that are in accordance with the waterfront city theory used are the themes of development, water use and activities that are appropriate even though there is still a need for additional activities so that visitors do not feel bored.

3. Arab Village AL Munawar

The Al Munawar Arab Village area is not in accordance with the waterfront city theory, so it needs development in accordance with its potential, such as land use that has not been used, optimizing ease of achievement, cleanliness and beauty of the environment for visitors' convenience and environmental sustainability, and maintaining climate local in the process of development. The actual conditions on non-physical aspects that are in accordance with the waterfront city 
theory used are the themes of development, water use and activities that are appropriate even though there is still a need for additional activities so that visitors do not feel bored.

\section{Kemaro Island}

The area on Kemaro Island is in accordance with the waterfront city theory. Even though it is already appropriate, on Kemaro Island there is still a need for additional pedestrian space for visitors so that the landscape arrangement aspect is fully in accordance with the theory used. Related to the nonphysical aspects are also in accordance with the theory used, where on the island of Kemaro the people have used river water as livelihoods and tourism activities and the development theme is very thick with the existing local climate, namely as a heritage of the Srivijaya kingdom mixed with Buddhist architecture.

\subsection{Constraints - Development}

There is still a lack of the role of the government as a facilitator in efforts to develop the waterfront city as a destination product in the Musi River region and also in the lack of education in the form of education related to the importance of preserving the environment. This makes the community understand the development program that will be carried out and also facilitate coordination between the community, the government and the private sector appointed to carry out waterfront city development in the Musi river area.

\subsection{Steps for Development}

The strategy in the effort to develop waterfront city as a destination product in the Musi River region, is to build strong coordination between tourism stakeholders in the waterfront city as a tourist destination product. With this strategy, making various interests of each stakeholder can be controlled in its development.

\section{SUGGESTION}

1. Increase the number of litter boxes, to reduce the tendency of visitors to dispose of waste in its place.

2. The government and community work together to plant green plants in every waterfront city area, which is useful for reducing noise and also the heat of the sun.

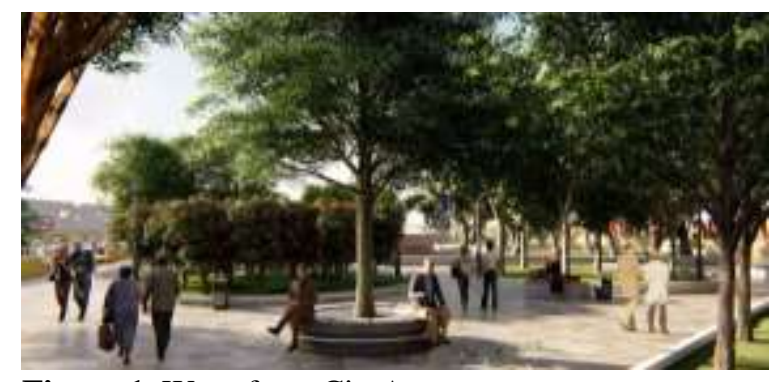

Figure 1. Waterfront CityArea

Source: author's work, 2019

3. It is better, in developing efforts to maintain local wisdom as an attraction.

4. It is better, in developing efforts to utilize unused land as a place for activities and facilities for visitors who pay attention to environmental sustainability.

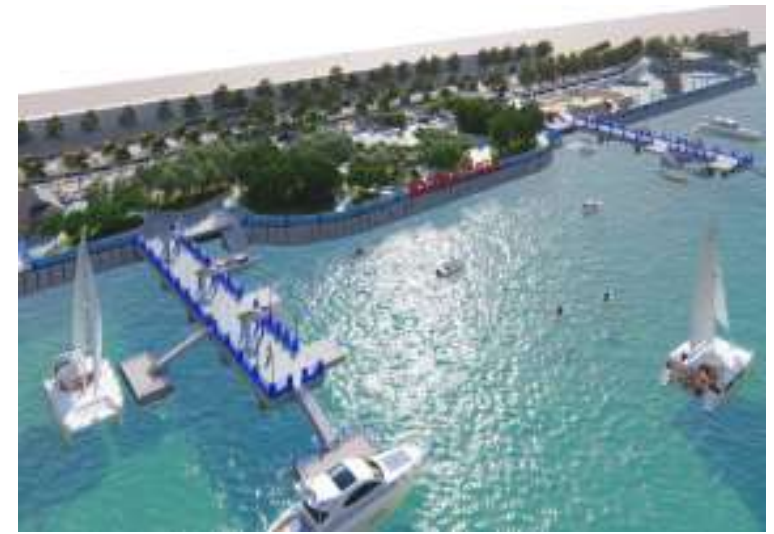

Figure 2. Unused land as a place for activities Source: author's work, 2019

5. It is recommended that the government and the community cooperate in developing new tourism activities so that tourists do not feel bored.

6. It is better, in developing efforts to maintain the theme of the bukding of historuc architecture an attraction

7. it is better to provide an oppurtunity for the community to aspire to carry out their development

8. It is better to increase the synergy between the government, the private sector and the local community as the host. With this, the constraints faced can be overcome properly so that efforts to carry out waterfront city development as tourism products in the Musi River area are optimal. The role of the private sector must also be considered, because the private sector is the party that invests in this waterfront city, in order to 
develop the region as a successful destination.

9. Preferably, the government involves a large role in the local community in developing efforts. The role in question is to give trust to the community in determining the direction of the development model based on the local wisdom held in each place. This is so that in the implementation of achieving harmony, harmony and integration in carrying out the task. The strategy is to build strong coordination between stakeholders in tourism in the waterfront city as a tourist destination product.

\section{AUTHOR'S CONTRIBUTIONS}

Pandita Nandana: Performed research, lead author, co-analyzed data, research site survey. Muhammad Iqbal Djohan: Corresponding authors, analyzed data, co authors, research site survey. Handika Fikri Pratama: Performed research, co-authors.

\section{ACKNOWNLEDGMENTS}

Special thanks to Tourism and Culture Department Government of South Sumatera Province, and all the participants in the research location.

\section{REFERENCES}

[1] Ann Breen \& Dick Rigby, (1994), Waterfront, Cities Reclaim Their Edge, Mc.Graw-Hill, Inch., Newyork

[2] Arikunto, S (2010). Prosedur Penelitian Suatu Pendekatan Praktik (edisi revisi) Jakarta: Rineka CiptaBandung : Penerbit ITB

[3] Banister, P. B. (1994). Qualitative Methods in Psychology, A Research Guide. Philadelphia: Open University Press.

[4] Basrowi \&Suwandi (2008). MemahamiPenelitian Kualitatif. Jakarta: Rineka Cipta.

[5] Basuki, Sulistyo (2010). Metodelogi Penelitian Jakarta: Penaku

[6] Carr, Stephen, dkk. (1992). Public Space, Combridge University Press. USA. Diakses dari http://ejournal.uajy.ac.id/9768/3/2TA14089.pdf

[7] Damanik, Janianton dan Weber, Helmut (2006). Perencanaan Ekowisata Dari Teori ke Aplikasi. Yogyakarta: PUSPAR UGM dan Andi.

[8] De Chiara, Joseph \& Koppelman, Lee, (1969). Planning Design Criteria, New York: Van
Nostrand Reindhold Company. Diakses dari https://jurnal.ugm.ac.id/jsp/article/view/10913

[9] Huberman,Miles (2013) Metodologi Penelitian Kualitatif. Jakarta.Universitas Indonesia Press

[10] Jacobs, J., (1993). The Death and Life of Great American Cities. Vintage Books. New York.

[11] Karo Karo, P., Iqbal, M., \& Dian Fitriansyah, Y. (2020). Analysis of Satellite City Readiness Effect towards Organization of Sport Events in South Sumatra Province. 111(Icoborot 2018), 55-65. https://doi.org/10.2991/icoborot18.2019 .9

[12] Masrul (2008). Pusat Penelitian dan Pengembangan Pemukiman (Departemen Pekerjaan Umum Republik Indonesia), Diakses dari

[13] Moleong, Lexy (2006). Metodologi Penelitian Kualitatif. PT. Remaja Rosdakarya. Bandung. Diakses

dari https://www.goodreads.com/book/show/63884 $\underline{\text { 82-metode-penelitian-kualitatif }}$

[14] Peraturah Daerah Kota Palembang Nomor 15 Tahun (2012). Tentang Rencana Tata Ruang Wilayah (RTRW) Kota Palembang Tahun (2012 - 2032)

[15] Peraturan Pemerintah Republik Indonesia Nomor 50 Tahun (2011). Tentang Rencana Induk Kepariwisataan Nasional Tahun (2015 - 2025).

[16] Sekaran, Uma (2011). Research Methods For Business: A Skill Building Approach. New York-USA: Jhon Wiley and Sons. Inc

[17] Shirvani, (1985), The Urban Dedsign Proses, Van Nostrand Reinhold Company, Inc, New York. Diakses dari http://ejournal.uajy.ac.id/6139/3/MTA201865.pdf

[18] Sukmadinata, (2006). Metode Penelitian Kualitatif. Bandung : Graha Aksara

[19] Torre, L. A.(1989). Waterfront development. New York: Van Nostrand Reinhold. Diakses dari

https://core.ac.uk/download/pdf/11718089.pdf

[20] Ulber, Silalahi (2009). Metode Penelitian. Bandung : PT. Refika Aditama.

[21] Undang - Undang Republik Indonesia Nomor 7 Tahun (2004). Tentang Sumber Daya Air.

[22] UN-WTO ST-EP Foundation (2011). Introduction To Sustainable Tourism. Seoul : UN-WTO ST-EP Foundation

[23] Warpani, P.Suwardjoko. (2002). Pengelolaan Lalu Lintas dan Angkutan Jalan. 